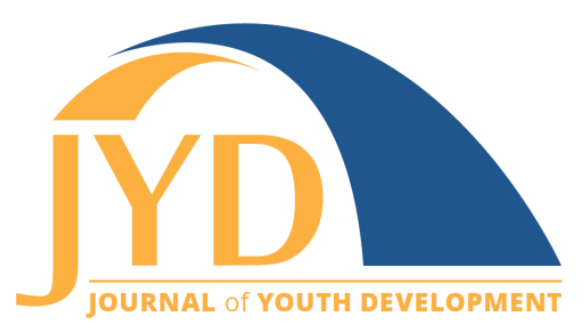

http://jyd. pitt. edu/ | Vol. 14 Issue 4 DOI 10.5195/jyd.2019.915 | ISSN 2325-4017 (online)

\title{
Video Review: History of Afterschool in America
}

\section{Maureen Toomey}

University of Idaho 4-H Youth Development

mtoomey@uidaho.edu

\begin{abstract}
After-school and out-of-school time programs are common across the United States and are seen as providing safe and nurturing environments for children, youth, and teens. The History of Afterschool in America documentary succinctly lays out the evolution of after-school and out-of-school time programming. The 60-minute documentary is framed in 12 chapters with narrative from historians, key advocates and leaders, practitioners, and teens. An accompanying learning guide provides discussion questions, key words and phrases, and additional resources. It is a must watch for after-school professionals, youth-serving organizations, and collaborators.
\end{abstract}

Key words: after-school, out-of-school programs, youth development

The History of Afterschool in America documentary succinctly lays out the evolution and growth of after-school and out-of-school time (OST) programming. The 60-minute documentary is framed in 12 chapters (Table 1) with narrative from historians, key advocates and leaders, practitioners, and teens. This documentary furthers the discussion around key themes of preconditions and demands for child supervision, serving low-income children, lessons learned, and current trends. Interestingly, early after-school efforts, beginning in the 1920s, attempted to address similar themes as today, such as providing safe and nurturing places for children, serving low-income children, and supporting parents to raise healthy and successful children.

(cc) $\mathbf{E Y}$ New articles in this journal are licensed under a Creative Commons Attribution 4.0 License. This journal is published by the University Library System, University of Pittsburgh and is cosponsored by the University of Pittsburgh Press. The Journal of Youth Development is the official peer-reviewed publication of the National Association of Extension 4-H Agents and the National AfterSchool Association. 
Video Review: History of Afterschool in America

Table 1. History of Afterschool in America Sections and Chapter Descriptions

\begin{tabular}{|c|c|c|}
\hline Section and chapter & $\begin{array}{l}\text { Viewing length } \\
\text { and time counter }\end{array}$ & Key concepts \\
\hline \multicolumn{3}{|c|}{ Section 1 - Pre-conditions and early history } \\
\hline Chapter 1: Introduction & $\begin{array}{l}1: 40 \\
(0: 00-1: 40)\end{array}$ & $\begin{array}{l}\text { Overview and defining terms of } \\
\text { afterschool and the field }\end{array}$ \\
\hline $\begin{array}{l}\text { Chapter 2: Social Upheaval, } \\
\text { Industrialization, and Child Labor }\end{array}$ & $\begin{array}{l}5: 15 \\
(1: 40-6: 55)\end{array}$ & $\begin{array}{l}\text { Industrial Era, immigration patterns, and } \\
\text { social conditions effects on children }\end{array}$ \\
\hline $\begin{array}{l}\text { Chapter 3: The Progressive Era } \\
\text { and Public School }\end{array}$ & $\begin{array}{l}3: 59 \\
(6: 56-10: 55)\end{array}$ & $\begin{array}{l}\text { Beginning of compulsory education and } \\
\text { effects on children and families }\end{array}$ \\
\hline $\begin{array}{l}\text { Chapter 4: The Need for Child } \\
\text { Supervision After School }\end{array}$ & $\begin{array}{l}2: 31 \\
(10: 56-13: 27)\end{array}$ & $\begin{array}{l}\text { Unsupervised children and tenement } \\
\text { housing conditions }\end{array}$ \\
\hline $\begin{array}{l}\text { Chapter 5: The Playground } \\
\text { Movement and the Beginning of } \\
\text { Youth Programs }\end{array}$ & $\begin{array}{l}2: 54 \\
(13: 28-16: 22)\end{array}$ & $\begin{array}{l}\text { Funding and building playgrounds in } \\
\text { urban centers }\end{array}$ \\
\hline $\begin{array}{l}\text { Chapter 6: Afterschool Responds } \\
\text { to Emerging Issues }\end{array}$ & $\begin{array}{l}1: 31 \\
(16: 23-17: 54)\end{array}$ & $\begin{array}{l}\text { Responding to World Wars I \& II, the } \\
\text { Great Depression, poverty, and changes } \\
\text { in workforce }\end{array}$ \\
\hline \multicolumn{3}{|c|}{$\begin{array}{l}\text { Section } 2 \text { - Influences that shaped the modern afterschool movement and the emergence } \\
\text { of new models }\end{array}$} \\
\hline $\begin{array}{l}\text { Chapter 7: Influences that Drove } \\
\text { the Expansion of Afterschool }\end{array}$ & $\begin{array}{l}6: 52 \\
(17: 55-24: 47)\end{array}$ & $\begin{array}{l}\text { Key research reports on crime } \\
\text { prevention strategies, addressing the } \\
\text { achievement gap, and changes in family } \\
\text { structure }\end{array}$ \\
\hline $\begin{array}{l}\text { Chapter 8: "School as Place," } \\
\text { Advocacy and Asset Model }\end{array}$ & $\begin{array}{l}7: 29 \\
(24: 48-32: 17)\end{array}$ & $\begin{array}{l}\text { Community and school-based } \\
\text { programming featuring Beacon Schools } \\
\text { and LA's Best as models }\end{array}$ \\
\hline $\begin{array}{l}\text { Chapter 9: Going to Scale with } \\
\text { Public Dollars and Foundation } \\
\text { Support }\end{array}$ & $\begin{array}{l}5: 24 \\
(32: 18-37: 42)\end{array}$ & $\begin{array}{l}21^{\text {st }} \text { Century Community Learning } \\
\text { Centers, California After School } \\
\text { Education \& Safety Program/Proposition } \\
49, \text { and public-private sectors }\end{array}$ \\
\hline $\begin{array}{l}\text { Chapter 10: Youth Outcomes, } \\
\text { Accountability, Quality, and Older } \\
\text { Youth }\end{array}$ & $\begin{array}{l}6: 22 \\
(37: 43-44: 05)\end{array}$ & $\begin{array}{l}\text { Realistic outcomes focused on the needs } \\
\text { of youth }\end{array}$ \\
\hline
\end{tabular}


Table 1 (continued)

\begin{tabular}{|l|l|l|}
\hline Section and chapter & $\begin{array}{l}\text { Viewing length } \\
\text { and time counter }\end{array}$ & \multicolumn{2}{l|}{ Key concepts } \\
\hline Section 3 - Historical themes and important new trends and the future of afterschool \\
\hline $\begin{array}{l}\text { Chapter 11: Historical Themes } \\
\text { and Important New Trends }\end{array}$ & $\begin{array}{l}15: 14 \\
(44: 06-59: 20)\end{array}$ & $\begin{array}{l}\text { Learning across contexts - STEM, the } \\
\text { arts, social-emotional, and summer } \\
\text { learning }\end{array}$ \\
\hline $\begin{array}{l}\text { Chapter 12: The Future of } \\
\text { Afterschool }\end{array}$ & $\begin{array}{l}1: 58 \\
(59: 21-1: 03: 40)\end{array}$ & $\begin{array}{l}\text { Equity in afterschool programming and } \\
\text { expectations based on future needs and } \\
\text { trends }\end{array}$ \\
\hline
\end{tabular}

\section{Description}

The influx of immigrants from 1880 to 1915 gave rise to a huge adult and child labor force. During this Industrial Era and Great Immigration, movement of people from rural to urban areas was marked by the desire for and availability of cheap labor. Children were working in abusive environments and were severely underpaid. Throughout the Progressive Era (18901920) child labor, immigrant needs, and compulsory education issues were addressed. Historian Gordon Alexandre engagingly maps out the societal changes that led to settlement houses and other non-profits' efforts to support the needs of immigrant families and the gap between a safe school day and after-school hours. The playground movement began during this time with funding from municipal governments in nine urban areas. These playgrounds provided a safe space to play and had some adult supervision. However, they were limited and did not solve underlying issues of safe housing and environments and equity in access to education and social well-being.

Between the 1930s and 1960s, municipalities and non-profit organizations responded to the need for the overall protection of children, creating safe places for socialization, addressing nutrition and hunger issues and childcare for women in the workforce. Robert Granger, former president of the William T. Grant Foundation, states that during this time "after-school is responding to needs of society, not driving their own agenda."

It was not until the 1980s that the after-school field shifted thinking from filling the gap between school and after-school hours to defining quality after-school programming and looking at the field as worthy of professional development standards. The community school concept 
gave rise to collaboration between the education, governmental, business, and non-profit sectors. At this point the documentary astutely lays out the transition of three justifications for programming (juvenile crime prevention, changes in the family structure and women in the workforce, and addressing the academic achievement gap). The transition came as a result of two key reports: A Matter of Time (Carnegie Council on Adolescent Development, 1992) and collective research gathered by the law enforcement sector, known as Fight Crime: Invest in Kids (Newman, Fox, Flynn, \& Christenson, 2000). Contributing to the changes was the work of Dr. Jackie Eccles, which better defined the qualities of developmentally appropriate settings and characteristics for young people to achieve (Eccles \& Gootman, 2002). The after-school and OST fields were shifting from seeing children from a deficit model of needing to be fixed to one of positive youth development with the ability to engage and achieve. In addition to key reports and research, strategic entities converged leading to what is now an accepted mode of operation: public-private partnership.

With the rapid rise in $21^{\text {st }}$ Century Community Learning Centers $\left(21^{\text {st }}\right.$ CCLC) and state funding, the after-school field held itself accountable. The documentary captures the challenge of developing accountability indicators. The last chapters focus on quality indicators, from improving standardized test scores to improving program quality and a focus on the healthy development of the children. With the growing technology sector came the push for afterschool science, technology, engineering, and math (STEM) programming. More recently, the arts have been included as a method to support STEM learning. With the influx of continual funding also came resources for summer programming to reduce academic loss over the summer break. There was a realization that social and emotional learning were critical factors to ensure healthy childhood development. By the mid-2000s the after-school field accepted that learning happens across a number of contexts and that the practitioner's role was to ensure that academic and well-being success skills are obtainable and equitable for all children from low- and moderate-income families.

\section{Considerations for Use}

The producers provide an excellent learning guide with timing and chapters noted (Piha, Daraio, \& Cruz, 2019). The guide breaks the documentary into three sections, each with discussion questions, keywords and phrases, and links to additional resources. It also includes a historical timeline and biographies of research interviewees. 


\section{Video Review: History of Afterschool in America}

Potential uses of this documentary include:

- Professional development training for after-school programs and youth-serving organizations

- Higher education institutions offering degrees in youth development-related fields (e.g., Parks, Recreation, and Leisure Studies)

- Screenings for potential stakeholders to fully understand the convergence of public and private sectors in support of extended learning opportunities

The History of Afterschool in America is an excellent overview of the evolution of out-of-school programming, the efforts to serve youth from limited resourced families, and a synopsis of the current trends. However, it does not take a deep dive into the contribution of community partners and organizations that have contributed to the field and supported the $21^{\text {st }}$ CCLC programs. Scouting programs, 4-H youth development, and the multitude of recreational sports organizations have made significant contributions to quality OST and after-school and could be noted in a sequel documentary. Additionally, other federal funding has flowed into the afterschool field, for example the Children Youth and Families At Risk initiative and those funded by the Juvenile Justice and Delinquency Prevention Act. As well, the YMCA and Boys \& Girls Clubs of America have been dedicated to increasing equity in extended learning for all youth. Thriving and successful youth development happens across the spectrum of OST and after-school programs with public-private partnerships and funding.

\section{How to Obtain}

The History of Afterschool in America, learning guide, and media kit may be downloaded at How Kids Learn (http://www.howkidslearn.org/) or by requesting a DVD.

\section{References}

Carnegie Council on Adolescent Development. (1992). A matter of time: Risk and opportunity in the nonschool hours. New York, NY: Carnegie Corporation. Retrieved from https://www.carnegie.org/publications/a-matter-of-time-risk-and-opportunity-in-the-nonschoolhours/

Eccles, J. S., \& Gootman, J. A. (Eds.). (2002). Community programs to promote youth development. Washington, DC: National Academies Press. 
Journal of Youth Development | http://jyd.pitt.edu/ | Vol. 14 Issue 4 DOI 10.5195/jyd.2019.915

Video Review: History of Afterschool in America

Newman, S. A., Fox, J. A., Flynn, E. A., \& Christenson, W. (2000). America's after-school choice: The prime time for juvenile crime, or youth enrichment and achievement. Washington, DC: Fight Crime: Invest in Kids.

Piha, S., Daraio, S., \& Cruz, R. (2019). History of afterschool in America: Learning guide. How Kids Learn Foundation and Temescal Associates. Retrieved from http://www.howkidslearn.org/ 